\title{
Evaluation of Value Capture Strategies for Public Private Partnership Projects in Railway System Projects to be Built in Istanbul City
}

\section{İstanbul Şehrinde İnşa Edilecek Raylı Sistem Projelerinde Kamu Özel İşbirliği Projeleri için Değer Yakalama Stratejilerinin Değerlendirilmesi}

\author{
Hakan İNAÇ ${ }^{1}$ (D) Cem Çağrı DöNMEZ² \\ ${ }^{1}$ Marmara University, Engineering Management Science, 34722, Istanbul, Turkey \\ ${ }^{2}$ Marmara University, Department of Industrial Engineering, 34722, Istanbul, Turkey
}

\begin{abstract}
For urban rail lines, there is a need for resources at all stages such as planning, construction and operation. In financing these structures with large budgets and requiring specialized construction, it is possible to implement not only the use of state resources but also many models of Public-Private Partnership (PPP).

This method, which can be called alternative financing, will make a significant contribution to the realization of investment auctions and will also contribute to the rapid commissioning / finalization of investments. This model has been tried many times in the world and it has been evaluated that it will be more successful for all the types of the metro (cable car, light subway, monorail, street tram which can be called as a relatively light subway investment.

For rail lines when alternative financing is required, it would be appropriate to increase the diversity of income items in feasibility reports. In this context, in addition to travel revenues, real estate value tax, Tax credit financing, goodwill and real estate development partnership can provide income. Real estate prices increase in the area where rail system investment is made and this situation is used as a direct marketing tool by construction companies. On the other hand, in cases where Station structures have to be constructed outside the public area, the cost of expropriation for the project is increasing and financing needs are increasing.

For the transportation investment projects carried out as Public-Private Partnership Project (PPP), the use of value increase strategies other than passenger revenues will be beneficial in terms of financing. The demographic and geographic features of the project will be decisive in the determination of the Value Capture Strategies (VCS) to be used.

Within the scope of this project; VCS strategies were evaluated in PPP models by using analytical hierarchy process (AHP) with expert opinion in rail system projects to be carried out in Istanbul.
\end{abstract}

Keywords: Alternative Funding Options, Value Capture Strategies (VCS), Public-Private Partnership (PPP), Rail System, Analytic Hierarchy Process (AHP), Istanbul

$\ddot{\mathbf{O z}}$

Şehir içi raylı sistem hatları için; planlanma, yapım ve işletme gibi tüm aşamalarda birçok kaynak ihtiyacı bulunmaktadır. Büyük bütçeli ve inşaatı ihtisas gerektiren bu yapıların finansmanında, sadece devlet kaynakları kullanımı değil birçok kamu özel işbirliği modelinin de hayata geçirilmesi mümkün görülmektedir.

Alternatif finansman olarak adlandırılabilecek bu yöntem, yatırım ihalelerinin gerçekleştirilmesinde önemli katkı sağlayacağı gibi, yatırımların hızlı bir şekilde hizmete alınması / sonuçlandırılmasında da katkı sağlayacaktır. Bu model dünyada birçok kez denenmiş ve göreceli olarak hafif metro yatırımı olarak isimlendirilebilecek metro türlerinde (teleferik, hafif metro, havaray, cadde tramvayı) daha başarılı olacağ1 değerlendirilmiştir. 
Alternatif finansmanı istenen raylı sistem hatları için, fizibilite raporlarında gelir kalemlerinin çeşitliliğin artırılması uygun olacaktır. Bu kapsamda yolculuk gelirlerinin yanında, Gayrimenkul Değer Vergisi, Vergi Artış Yoluyla Finansman (Tax Increment Financing), Şerefiyeler ve Gayrimenkul Geliştirme Ortaklığı gibi yöntemler ile gelir sağlanabilecektir. Özellikle, raylı sistem yatırımları metropol şehirlerde emlak fiyatlarını doğrudan etkilemektedir. Raylı sistem yatırımı yapılan alanlarda gayrimenkul fiyatları artmakta ve bu durum inşaat firmaları tarafından doğrudan bir pazarlama aracı olarak kullanılmaktadır. Diğer taraftan istasyon yapılarının kamu alanı dışında inşa edilmesi zorunluluğu olduğu durumlarda proje için kamulaştırma maliyeti oluşturmakta, finansman ihtiyacı artmaktadır.

Kamu-Özel İşbirliği Projesi (PPP) olarak yapılan ulaştırma yatırım projeleri için, yolcu gelirleri dışındaki değer artış stratejilerinin kullanılması finansmanın sağlanması açısından faydalı olacaktır. Kullanılacak Değer Yakalama Stratejileri'nin (VCS) belirlenmesinde ise, projenin demografik ve coğrafi özellikler belirleyici olacaktır.

Bu proje kapsamında; İstanbul'da yapılacak raylı sistem projelerinde uzman görüşü ile Analitik Hiyerarşi Süreci (AHP) kullanılarak, PPP modellerinde VCS stratejileri değerlendirilmiştir.

Anahtar Kelimeler: Alternatif Fonlama Seçenekleri, Değer Yakalama Stratejileri (VCS), Kamu-Özel Ortaklığı (PPP), Raylı Sistem, Analitik Hiyerarşi Proses (AHP), İstanbul

\section{INTRODUCTION}

Project financing can be defined as the provision of resources necessary and adequate for the construction of a new project or the development of an existing project [1].

Trends in PPP projects in the construction and operation of railway system lines are on the rise. Until 2013, during the last 25 years, we have passed, 27 PPPs have been passed on to the project. 16 of these projects were made in Europe. The positive side of these collaborations is that they are innovative and able to finance projects that are impossible to pass through. The downside of PPP projects is that the budget is a risk of financing more expensive than the specified costs. PPP projects also have unsuccessful modelling of railway financing. [2]. A good study and Value Capture Strategies (VCS) should be studied for this purpose.

When the studies of PPPs are examined; it has been seen that studies are analyzed in 4 different project types. In this approach, construction and operating costs, income expectancy, and ease of financing are analyzed:

(i) High Speed Rail

(ii) Airport Rail Links

(iii) Equipment / Rolling Stock

(iv) Conventional Rail
It is stated that the studies are in various public-specific regulations such as business concessions, division, joint ventures, special infrastructure as well as public transport such as light rail system, subway, human transport [3].

In accordance with the budget draft of 2015 published by Istanbul Metropolitan Municipality (IMM), capital expenditures including Istanbul-wide investments took place as $51.11 \%$ of total municipal expenses. The biggest share of capital expenditures is the transportation services management. For example, the IMM foresees that this share would be $44.7 \%$ of capital expenditures in 2016 [4]. Rail system investments in transportation services take the biggest share in the investment category. The development of alternative financing methods for rail system investments will alleviate the burden on the budget, as well as increase the appropriations allocated to other investments.

In fact, Istanbul is the first in the world to use alternative financing methods in the construction of public transportation systems. Taksim Tunel Funicular Railway Line which was put into service in 1875 was operated by the private sector until 1939. The private sector operated 64 lines are still in use [13]. This system was built by the private sector as an operating transfer. However, 68 years later, due to non-travel incomes, a certain price was paid by the public and expropriated. This historic example also demonstrates the importance of value capture strategies for private sector investments.

In general, accessibility plays an important role in the construction of cities. Accessibility generally refers to the convenience of the passengers to go where they want to go. Rail systems with accessibility affect the attitudes and behaviours of households and companies, creating greater impacts such as land use and real estate valuation. These effects generate economic and social benefits for three segments $[5]$.

The first segment is the public opinion that provides direct or indirect gains from the economic and social benefits generated by rail system investments. Economic and social income is the basis for the allocation of tax revenues from the general budget in financing railway system investments. The second segment is rail system users. For this segment, rail systems benefit by reducing travel times and providing adequate transportation capacity in a comfortable and economical way. Such benefits are the basis for the financing and operation of rail systems to provide financial resources in different ways than the passengers.

The third segment is the construction companies that develop real estate in the land of the owners of the real estate located in the vicinity of the rail system lines and the 
construction companies that develop real estate in the land near the lines or stations.

When housing land prices are examined, the distribution of land prices across neighbourhoods is also effective beyond socio-economic conditions, population density, development status and land availability. For this reason, land prices may be high in the neighbourhoods that are behind in the housing price rankings. Housing prices for the sale of low value are concentrated in Silivri, Çatalca and Arnavutköy districts, where the prices are mainly far from the city centre, population density is low and the availability of empty land is high. The zoning situation (for example, in water basins) is determinant over the low price. In the prices of agricultural land for sale, there are neighbourhoods where Villa type buildings are mainly connected to the districts of Eyüp, Sariyer and Beykoz. Therefore, the price rise in these neighbourhoods can be thought to be due to the possibility of a possible zoning change, rather than the use of these lands as my style land [6].

This research will contribute to the evaluation of the railway system investments to be made in Istanbul with the PPP model. In this work, the value increases of public investments directly and indirectly in private properties were examined together with literature examples in the world. Value-added strategies for Istanbul were handled with public administrations, construction contractors and real estate appraisers. It has been proposed in this study that the selection of appropriate PPP models and which alternative financing methods can be used. In addition, the PPP model and the VCS were discussed in this work. This approach will contribute to the establishment of a suitable PPP cooperation model for a city.

\section{LITERATURE SURVEY}

The biggest challenge facing the construction of rail system projects is financing. Providing financial sources for the rail systems requiring high investment profiles, is easier by using VCS and PPP evaluations.

\section{I.I. Value Capture Strategies}

In both theoretical and empirical studies, there are important findings that investing in the leased system increases the value of real estate [6]. In recent years, in the literature, it has come to the fore to support investment in referrals by value acquisition (value capture). The methods known as VCS in the literature refer to mechanisms that allow the transfer of the resulting value increases to the public investment to be used in the financing of public investments.
They have comprehensively catalogued VCS that the US has created for the Minnesota State Assembly by creating reproductive systems [4].

Organizations that make investments in this system are;

(i) Split-rate property tax,

(ii) Tax increment financing,

(iii) Special assesment district,

(iv) Joint development,

(v) Air rights,

they can provide a source of value increases created by railed systems.

The theme of the real estate value tax is on the land and land, and the application is different from country to country. In the United States (USA), the tax-sharing system is widely applied as a split-rate property tax. In this taxation system, a real estate is subject to taxation in two different ratios. The higher rate is applied to the land of the real estate while the lower rate is applied to the structure constructed on the land. In our country, the real estate value tax is the real estate tax. Since the local governments have no authority to create fiscal obligations such as taxes; the land-based tax application in Turkey is not possible with existing regulations.

\section{I.2. Value Capture Strategies Practices in Worldwide}

Value-added strategies have various practices around the world. The technical details of these applications vary depending on the country's legal legislation, socio-economic structures and habits. It is seen that value-added strategies in railway systems are applied more often in developed countries such as China, Japan and USA.

\section{I.2. I. Practices of real estate value tax method in the world}

Important applications of real estate value tax were made in the cities of Pennsylvania in the USA. From 1913 onwards, the provincial administration decided that a plot of land, both land and land, could be subject to taxation. After this darkness, many cities wanted to shift to a tax-rich system of taxation as a split-rate property tax in the literature [5]. In this system, a real estate is subject to taxation in two different ratios. The higher rate is applied to the land of the real estate while the lower rate is applied for the structure located on the land.

Another method of providing funds is known as "Tax Increment Financing" in the literature. Basically, this 
method seeks to allocate a share for the guided systems from the real estate tax collected from places where the value increases, the resulting transfer value increases which is invested to the public. This method is widely used for various projects in the northeastern states of the USA. As a result of the investments of the first stage rail system, the region where real estate appreciation increases will be determined. This region is called the financial district. The pre-tax base of all taxable real estate located in this region is determined. The collected tax revenues are used to finance the guided system because of the increases in the tax base during the period during the method is applied. The important point in this application is that tax revenues derived from pre-investment bases are not used for financing but only tax revenues derived from the value increases in the investment resultants. Thus, the investments in the backward system do not create an additional financing burden for the public.

\subsubsection{Practices of Tax Increment Financing in the World}

This method has been applied in the USA for various projects for the last 50 years. Nevertheless, the number of local governments using this method has increased in the last 15 years. Since 2005, all states have made legal arrangements that underpin the implementation of this method.

This method is widely used in many cities of the state of Illinois. By the end of 2005, 233 districts in the Cook district, 136 in the Chicago area and suburbs in the Chicago area were funded for various projects using this method. Only 10 per cent of the real estate value tax collected in Chicago alone is transferred to various projects within this method.

\subsubsection{Practices of Special Assesment District in the World}

In the third method of providing funds, the goodwill is taken into the measurements determined by the owners of the real estates where the end result value increase is realized. The appreciation of an immovable property is not limited to having a tracked system in the area it occupies. The reason for this is that the value increases due to the railed system have to be deducted from the prices to be paid due to factors other than the guided system. In practice, it is necessary to determine the real estate appreciation-effect area of the investment in railway system that gives goodwill. This area is called the special assessment district. The goodwill area refers to the geographical area that contains real estate that has increased in value to the area. Valuation gains are transferred to real estate holders located in the goodwill area by using various methods.

In general, local governments from the state governments in the United States have provided funding for transportation financing with this method. According to the 2002 figures, the revenues of local governments consist of $0.44 \%$ dividend honours.

The most important resource provision method is a real estate development partnership. A comprehensive method of real estate development partnership means that the public is funded by the private sector through the involvement of the private sector in potential real estate development projects resulting from investments in a zone-based system with an official agreement or arrangement between the public and private sectors. This method, which is widely used in the world, is different from country to country. This is an umbrella concept, and different sources of funding are known as real estate development partnerships. Real estate development is a multi-faceted business area and it involves various actions regarding building construction, marketing operation and management without developing the land. The methods were successfully applied in Hong Kong, Taiwan, Tokyo, Thailand, Washington, D.C., New York, Portland, Miami, Philadelphia.

A similar method is known as air rights. It aims to develop real estate on land allocated to public highways, railway system lines and stations with the air right method. The financial resources provided from the real estate projects developed on these landmarks are used in the construction and operation of highways, railways.

\section{I.2.4. Practices of Joint Development Method in the World}

Hong Kong Examples: Hong Kong is an autonomous region with a surface area of $10,104 \mathrm{~km}^{2}$ bound to the People's Republic of China, which is located on the southern coast of the People's Republic of China.

The Hong Kong Metropolitan Transit Railway Corporation (MTRC) uses the rail plus property model, shortly called as the R + P model, which he calls the real estate development partnership method, for construction and operation financing of rail systems income.

At the first stage of this model, the company buys the right to develop for the real estate around the station from the Hong Kong administration at pre-rail prices. It then establishes partnerships with real estate development companies, taking into account the high price of the after rail system. 


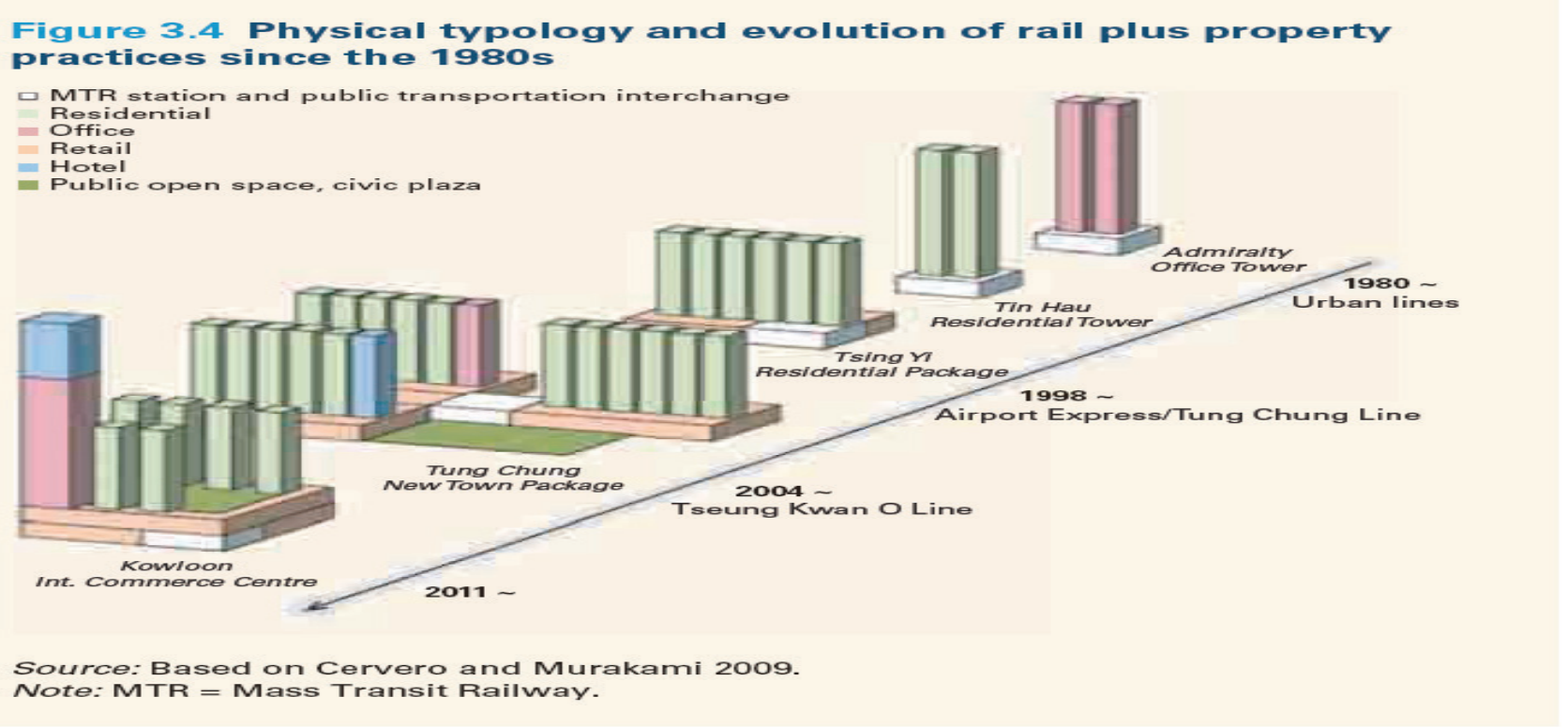

Figure 1. Under-Rail Property Model Applications in Hong Kong

In short, the company shares revenue in private-sector and real estate development projects using the rail plus property model and the right to develop it. The revenue sharing can be in different forms. For example, the company may ask the private sector for a portion of its revenue with up-front payments. In another application, the company can make a profit partnership with the private sector for the project and earn revenues from the post-project sales. Finally, the company may be entitled to the same payments after the project and may generate revenue from the sale or lease of these assets [7].

In the rail plus property model, the company undertakes the legal actions related to the project as well as the land use and design plans of the real estate development project (MTRC). In addition, the private sector, which is common to the project, undertakes the entire construction cost and risk of the project. Land usage may differ from project to project. Figure 1 shows real estate development projects in a station area along a line. For example, the first project made in 1980, the Admiralty Office Tower was constructed, while the mixed-use was made in the 2011 Kowloon International Center project [8].

\section{I.3. Public-Private Partnership (PPP)}

It is defined as the joint execution of public infrastructure projects by the private sector and the government. This type of projects are obtained by state and private firms which include investment, risk and financing based on responsibility and profit. The aim of the partnership between the public and private sectors is to be able to use the advantages of both sides in a common project. In different projects, the roles that parties can assume may be different [7]. In some partnerships, private sector firms play a dominant role in providing services, and sometimes they can stand out only in the construction and financing. Through such partnerships, efficiency gains in the provision of public infrastructure which is mainly used in investments and public services, design, financing, construction, operation and maintenance activities. Commonly used financing models for transportation projects in the World are listed below [8];

(i) Build-Operate-Transfer (BOT),

(ii) Build-Operate (BO),

(iii) Design-Build-Finance-Operate (DBFO),

(iv) Build-Own-Operate-Transfer (BOOT),

(v) Build-Own-Operate (BOO),

(vi) Build-Lease-Operate-Transfer (BLOT),

(vii) Securitization.

The advantages and disadvantages of these methods and their detailed explanations are also discussed.

\section{I.3.I. Build-Operate-Transfer (BOT)}

This model consists of the following steps. 
(i) The financing of a public infrastructure investment or service which requires advanced technology and / or large resources is realized by a private company,

(ii) Operated for a period determined by the public,

(iii) To sell the goods or services produced within the agreed time period to the public institutions in accordance with the tariffs mutually determined by the parties,

(iv) Deducting the facilities which are operated at the end of the period to the relevant public institutions which are maintained, complete and operational.

Build-Operate-Transfer model of practice in Turkey includes energy, free zones, air and sea ports. Examples of Energy Sector; Birecik Dam, Marmara Ereğlisi Natural Gas projects, including the BOT model is installed and is still operating 23 facilities.

World examples include the Severn Bridge between England and Wales (\$ 510 million), the Shajao power plant in China (\$530 million) and the TransAlaska pipeline in the United States.

\subsubsection{Build-Operate (BO)}

There is no permanent ownership of the private sector in the BOT model. A state monopoly is a contract carried out by a private company under a contractual framework and under its own control. For this reason, the facilities to be constructed are transferred to the state establishment at the end of the projected operating period. The build-operate (BO) model has been put forward as a result of criticism (phase of privatization, competition and economic life), which is the final stage in the build-operate-transfer (BOT) model. Accordingly, the $\mathrm{BO}$ model differs from the BOT model in that the facilities to be built in the framework of the agreement remain indefinitely owned by the private sector.

The fact that the entity will be transferred at the end of its economic life in the BOT model will prevent the operating company from postponing the restructuring investments in recent years and efficiently operate the entity without investing in significant amounts of renewal and technology. For this reason, the fact that such asset is constantly in the possession of the operating company necessitates investments in renewal and maintenance that will ensure efficient operation of the asset. The BO model, like the BOT model, is not competitive because both models create privileged companies. The contracts that are made give the buyers and/or the price guarantees to the companies. To eliminate all of these conditions and to enable companies to run their businesses in a competitive environment, it is necessary to decide in the upper-level sector to be created.

\section{I.3.3. Design-Build-Finance-Operate (DBFO)}

A private sector firm undertakes the design, financing and construction phases of a new project in the face of a long-term contract, but never takes ownership. The facility is transferred to the public after it is operated by the company during the contract period. The operating period is usually 25-30 years. Some of the prices can be subsidized by the public like the discovery fee. In general, however, it is the private joint responsibility for financing. The general advantage of this model is that it saves money from the financing of the project. The disadvantage is the rather complicated procedures encountered. The main difference from the BOT model is the development of a project design that is thought to be efficient by the private sector. In the BOT model, the work to be done is certain, the company only projects how to finance it.

Examples from the world are the Jose Petrochemical irrigation system in Venezuela, water treatment plants in Ohio.

\section{I.3.4. Build-Own-Operate-Transfer (BOOT)}

It is a frequently used model for high-budget infrastructure work (roads, bridges, dams), especially in Australia and developing countries. In this model, the private sector provides the necessary financing for the construction, builds the plant and owns and operates it for a certain period. This period is usually $15-30$ years. The facility is then transferred to the public by the company. This model is also supported by the World Bank, the Asian Development Bank and the European Development Bank.

Examples of the world include the Mangawhai Port wastewater plant in New Zealand, the Sydney Harbor Tunnel and Melburn CityLink projects in Australia and the Tha Ngone Bridge in Laos.

\section{I.3.5. Build-Own-Operate (BOO)}

It is the same as the build-own-operate-transfer model in terms of designing, financing and constructing the project. The difference between the $\mathrm{BOO}$ model is that the facility is not transferred to the public by the private sector at the end of a certain period of operation (right of indefinite operation). Instead, the government may make some arrangements for the operation of the plant. For example, the government may have a say in pricing.

An example is the $\$ 400$ million power plant planned to be built in Lithuania with American Calenergy, Duke energy and German Siemens partnership. 


\section{I.3.6. Build-Lease-Operate-Transfer (BLOT)}

It rents a project that builds the private sector and transfers ownership to the public, and sometimes other units related to the project for a certain period. This structure is used in cases where the project creates discomfort that the private sector owns. For example, it is desirable that motorways, bridges and tunnels are always in the public domain.

\section{I.3.7. Securitization}

This model consists of the following steps.

(i) Consolidation of revenue-generating assets,

(ii) The sale of these merger-based securities,

(iii) Making repayments of the securities sold with collected income.

In general, all assets whose future cash flows can be estimated at a certain level of confidence can be securitized. The way of financing through securitization is usually preferred if no resources can be reached due to the inability to reach the desired qualifying funds (maturity, interest, foreign currency) or due to the project risk.

\section{I.4. Advantages and Obligations of PPP Projects}

The most common types and evaluations of the Public Sector Partnership in practice are as follows;

\section{I.4.I. Operate-Maintenance}

A public entity is maintained and operated with a partner from the private sector. The proceeds are shared between the two partners.

Table 1. Advantages-Obligations for Operate-Maintenance

\section{Advantages:}

(i) Potential of increase in service quality and efficiency,

(ii) The savings to be provided in the costs of providing services,

(iii) Flexibility in determining contract conditions,

(iv) If the asset is in public ownership,

(v) They may respond late to changing market demands.

\section{I.4.2. Design-Build}

A public enterprise with a partner from the private sector is designed and built. Then, the public undertakes the operation, the share of the other common profit.

Table 2. Advantages-Obligations for Design-Build

\section{Advantages:}

(i) To benefit from the experience of the private partner,

(ii) To save on construction costs,

(iii) To gain flexibility in adapting innovations,

(iv) To put more risk on the private sector,

(v) Less problems in construction phases,

(vi) The main role of the work is to be able to control the results in one place.

\section{Obligations:}

(i) Decrease in public control,

(ii) Difficulties in making amendments to the contract,

(iii) Complex awarding procedures,

(iv) The low cost of capital provided is offsetting the high operating and maintenance costs that may arise due to the fact that the product-life cycle does not participate in the account.

\section{I.4.3. Turnkey Operation}

It provides public financing and private sector design and construction. The asset is operated by the private sector partner for a certain period of time. The public sets performance criteria and monitor its implementation. The entity concerned is in possession of the public. This path is used more often when the publicity is very important to ownership, and if the private sector is willing to take advantage of building and operating experience.

Table 3. Advantages-Obligations for Turnkey Operation

\section{Advantages:}

(i) The risk of building is in special partnership,

(ii) The specification, design and operation principles can be determined,

(iii) The fact that the operator has a special partnership for a certain period,

(iv) The public benefit derived from the efficiency of the private partner in construction,

(v) The construction should be completed in a short time.

\section{Obligations:}

(i) Decrease in control of the business,

(ii) Due to the complex award procedure,

(iii) Difficulties in making changes to the contract,

(iv) Depending on the project, financial risk can be assumed by the public. 


\subsubsection{Wrap Around Addition}

The private sector makes an addition to itself by providing its own financing of the existing asset. The amount of investment and a predetermined reasonable return run to the winner.

Table 4. Advantages-Obligations for Wrap Around Addition

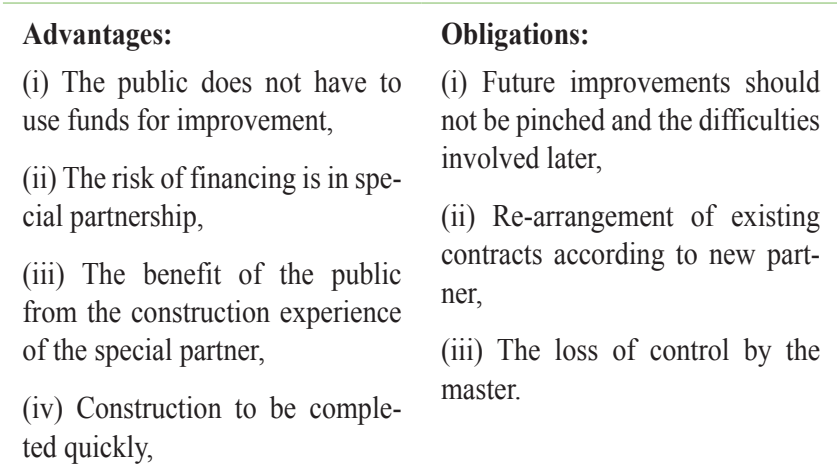

\section{I.4.5. Lease-Buy}

The private sector partner makes design, financing and construction. Then the public is renting for a certain period. At the end of the tenancy agreement, the public is transferred. This road is used more often when the public wants to set up a facility or provide a service but can not provide financing. Buildings, transportation fuels, and computer-equipment are often used to provide a way.

Table 5. Advantages-Obligations for Lease-Buy
Advantages:
(i) Rent payments may be less than debt interest payments,
(ii) The business risk is in the spe-
cial partnership,
(iii) Better service can be offered
cheaper,
(iv) Ensuring efficiency in cons- truction,
(v) It is possible to make a paid lease contract according to the performance.

Obligations:

(i) Decreased control over assets and operations.

\section{I.4.6. Lease-Develop-Operate /or/ Buy-Develop - Operate}

The private partner rents or buys an asset from the public. Then develop, modernize and operate. The private sector continues to run its investment to the partner and until a pre-determined income is won.

Table 6. Advantages-Obligations for Lease-Develop-Operate /or/ Buy-Develop - Operate

\section{Advantages:}

(i) If you purchase a private common entity, a significant cash entry is provided to the public,

(ii) The public does not use funds for improvement,

(iii) The risk of financing becomes the exclusive partner,

(iv) Revenue-generating opportunities are available for both partners,

(v) Improving facilities and services, providing better quality service to users,

(vi) The public benefit is obtained from the construction efficiency of the private partner,

(vii) Construction is completed quickly, (viii) The project is to be applied in a short time.

\section{Obligations:}

(i) Loss of control over assets,

(ii) Difficulties in determining the value of assets to be placed or leased,

(iii) Difficulties in selling or acquiring donated assets,

(iv) In case the private partner fails, it may have to re-commission to provide public service,

(v) If the future improvements need not be done, it is very difficult to add them later.

\section{I.4.7. Temporary Privatization}

A public asset is transferred to private sector development. The asset is owned, developed and operated by the private sector. When the private sector earns an investment that you have made and a predetermined reasonable return, the asset is returned to the public.

Table 7. Advantages-Obligations for Temporary Privatization

\section{Advantages:}

(i) If the contract is well prepared, standards and performance control can be done,

(ii) The transfer of assets reduces the management costs of the public,

(iii) Private partnership provides efficiency increase in construction and operation,

(iv) Private sector funds are reached for construction and operation,

(v) The business is on the exclusive partner of the risk.

\section{Obligations:}

(i) Loss of control over assets,

(ii) The contract should be prepared considering the anticipated problems in the future,

(iii) The private partner can set the charge for the usage fee to a high value determined by the public,

(iv) The difficulties of replacing a private partner or replacing it with another partner,

(v) The private partner is a potential competitor who can provide the same service in the future,

(vi) Public employees should be dismissed or transferred to a private partner. 


\section{I.4.8. Build-Transfer-Operate}

The public finds a partner for financing and construction. Once the asset is completed, it is transferred to the public. On the other hand, the asset is given to the private sector until the investment is made to its partner and a pre-determined reasonable income is earned.

Table 8. Advantages-Obligations for Build-Transfer-Operate

\section{Advantages:}

(i) Benefit from the construction experience of the special partner, (ii) Thanks to the operating experience of the private partner, costs are saved,

(iii) Asset is in public ownership,

(iv) The public controls the fees to be paid and the services to be provided,

(v) Operational performance and service standards are controlled by the public,

(vi) It can be replaced by a new private partner who can not provide performance standards.

\section{Obligations:}

(i) In case the private partner does not fit or perform, the contract is difficult to finish.

\section{METHODOLOGY}

The Analytic Hierarchy Process (AHP) is a general theory of measurement. It is used to derive ratio scales from both discrete and continuous paired comparisons. These comparisons may be

taken from actual measurements or from a fundamental scale which reflects the relative strength of preferences and feelings. The AHP has a special concern with departure from consistency, itsmeasurement and on dependence within and between the groups of elements of its structure. It has found its widest applications in multi-criteria decision-making, planning and resource allocation in conflict resolution. In using the AHP for modelling a problem one needs a hierarchic or a network structure to represent that problem and pairwise comparisons to establish relations within the structure [9].

Within the scope of this study, The Value Capture Strategies (VCS) and Public Private Partnership (PPP) varieties were evaluated using Analytic Hierarchy Process (AHP) with expert opinion for rail system projects to be carried out in Istanbul.

The objective of this study is "Selection of Suitable Alternative Financing for Railway Types in Istanbul". Four commonly used methods of value capture strategies were identified through literature review. Figure 2 shows the hierarchical view between the commonly used VCS and PPP methods prepared in the study.

The Value Capture Strategies have been compared to each other with expert opinions in Istanbul. The resulting weighting is presented in Figure 3.

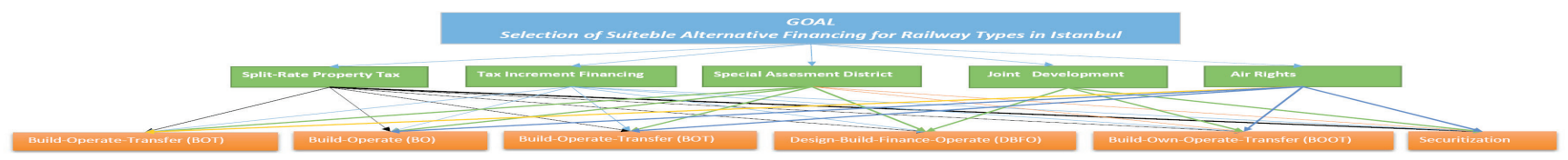

Figure 2. Value Capture Strategies Hierarchy View

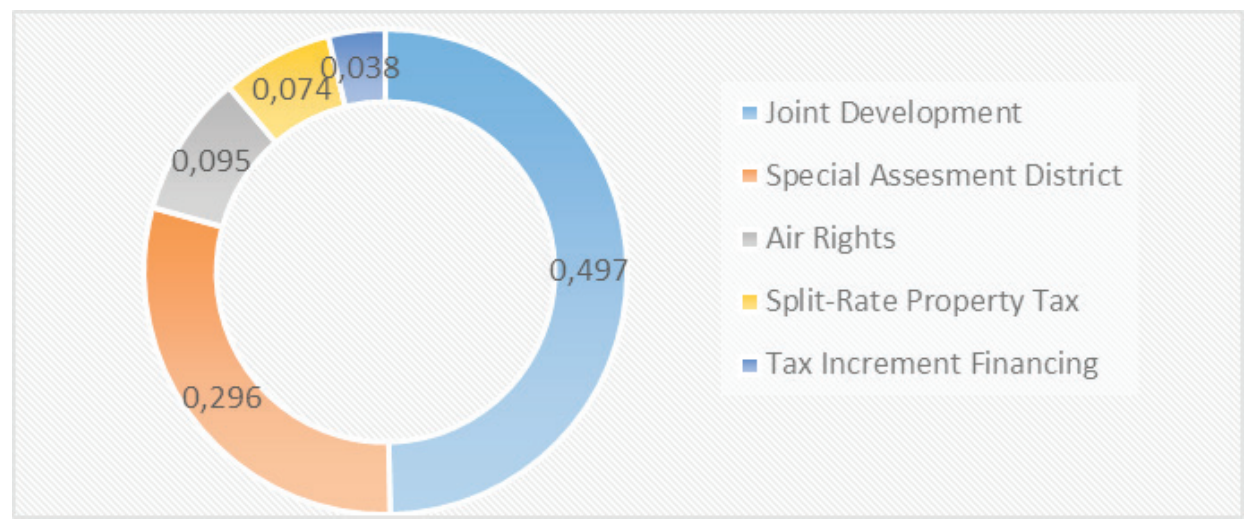

Figure 3. Value Capture Strategies Prioritization and Comparison Table. 
Comparisons have been made to find appropriate PPP Methods for VCS to be selected. Example A comparison of the partnership method for the Joint Development Strategies is presented in Figure 4.

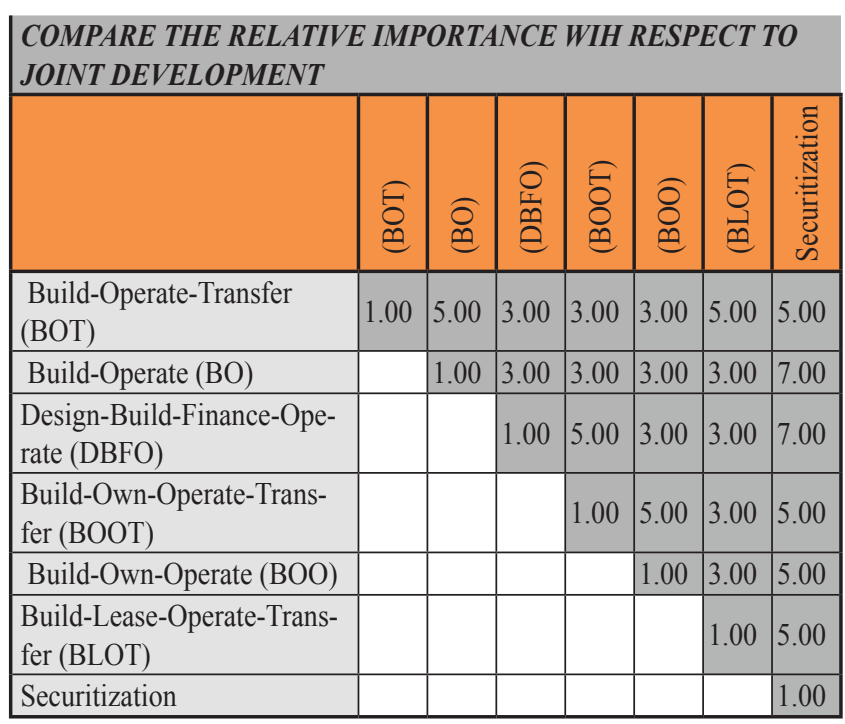

Figure 4. Partnership Method Comparison for Joint Development Strategy

When the results of the AHP evaluation are examined using the Expert Choice program shown in Figure 5, it is understood that cooperation with all processes in the projects to be developed with the private sector is required. In terms of the private sector; design, constraction, financing and participating in all of the business processes, minimizes the total cost of the projected systems and increasing the profitability. In terms of the public sector, this approach will not be a problem if passenger demand is met effectively.

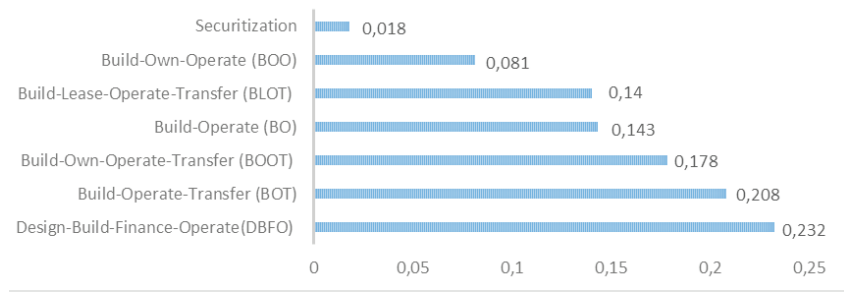

Figure 5. PPP proposal for railway system construction for Istanbul

The sensivity analysis shows that the selected BOT partnership model for İstanbul will change when the determined strategy turns to higher weighted Joint Development. When such a choice is made, the choice of Design Build-Finance-Operate (DBFO) will be a more appropriate partnership method. Figure 6. summarizes this situation.

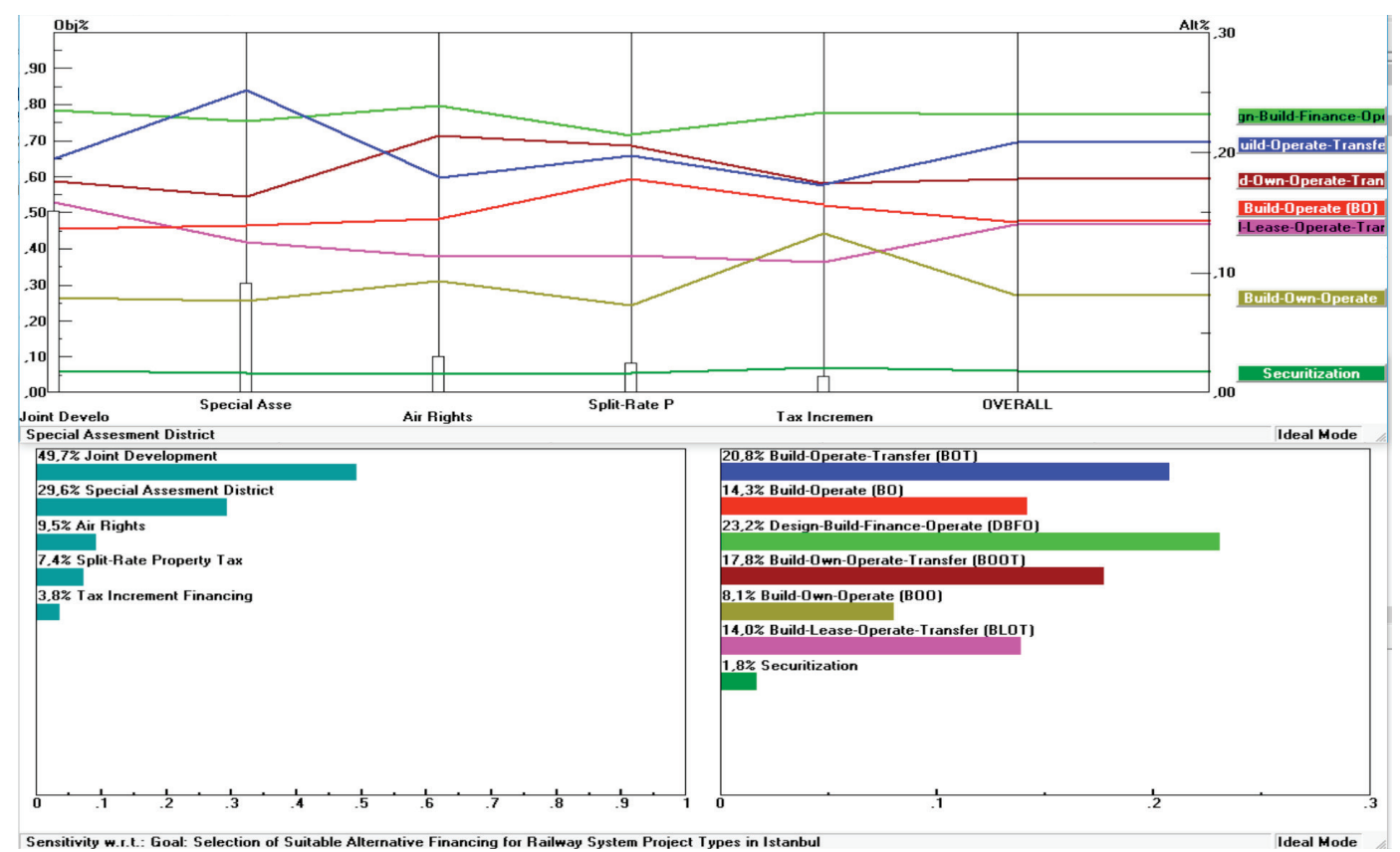

Figure 6. Sensitivity Analysis 


\section{V.FINDINGS and DISCUSSION}

Partnership models like PPP will make a significant contribution to Istanbul's achieving the $1.000 \mathrm{~km}$ guided system. With PPP it is possible to start service/ finalize investments quickly. However, it is not possible to finance only large-scale projects with travel and advertising revenues.

For PPP, feasibility studies with only traditional income items may not be enough. It will be useful to implement Value Capture Strategies for PPP jobs. Istanbul is a very attractive city especially in terms of real estate investment. It is seen that Joint Development is the most appropriate strategy for Istanbul when it is assessed with expert opinions for Istanbul as its value capture strategies. In such a case, the appropriate methods for PPP will be BOT and / or DBFO.

According to Fortune magazine, real estate prices in Istanbul have risen by $142 \%$ over the past 5 years. In new citywide real estate projects, proximity to railed system lines is used as a marketing strategy. It will be useful to develop this opportunity as Value Capture Strategies.

However, worldwide PPP financing models for public transport within the city have been implemented in very few cases. In the implementation of such projects, it is generally preferred to use low-cost rail systems (cable cars, light subways, aerials, street trams). Diversification of income items, especially with respect to real estate prices, will enable them to be used as financing in high-cost urban railway system projects.

About Istanbul For Value Capture Strategies, the evaluation notes of experts in face to face interviews are presented below. (Experts who made face to face interviews were not disclosed. In general, the public and private sector in the senior task, finance, subway management, public administrators and project managers of construction companies.)

1- It is possible to design such models with different varieties within themselves. In this context, each country needs to take advantage of its experience in BOT / PPP metro investments around the world, considering its own particular circumstances. (e.g. Milan Metro Line 4-5, Melbourne Metro, Hyderabad Metro, Salvador Metro, Beijing, Hong Kong etc.)

2- Upper use right; it is obvious that it will make a very important contribution to the funded system. The cost of the overuse is transferred to a special budget for use in railing system financing. In the BOT / PPP contract, the operation / rental period can be shortened. For the application;

a. Legal arrangements are required as discussed in the meeting. b. The feasibility of the project should be designed to maximize the use of the upper use, and the development plans should be provided.

c. The relevant area must be purchased by our municipality in the course of study.

3- It is possible to contribute to the financing and the guided system budget obtained by privatizing highincome lines for a certain period of time (e.g. 30 years).

4- Taxes should be levied under the name of systematic share from the sectors of urban transport in Istanbul (gasoline, bridges, all transportation service tickets, private vehicle consumption, etc.) as TRT share.

5- To increase the income of the existing lines, buses / minibuses etc., which are working on the same route. Some of the routes should be removed, but the routes that feed the lines should be added. Railway system integration should be put into effect for efficient use of the lines.

6- The names of the stations are given to the sponsor companies. Transfer of income from this to the budget of the rail system. (Such as Turk Telekom Uskudar Station)

7- BOT / PPP is generally not considered suitable by investors and / or creditors because the return times are long due to the high cost of the Metro investment. In order to make BOT / PPP metro investments attractive;

a. Warranty passenger and ticket price application,

b. Upper use right,

c. Advertisement income right,

d. Sponsor station name right,

e. Right to construct and operate a parking lot,

f. The right of construction and operation of the bazaar,

g. $50 \%$ of the operating energy cost paid by the Contracting Entity (reducing the financial burden on the Contractor)

h. Financing of a part of the work by the Administration. (For example, the cost of the electromechanical work will be paid by the Contracting Entity as a reward to reduce the financial burden on the Contractor).

8- More optimal solutions (low construction and operation cost, high customer satisfaction, fast construction methods) will be produced if the PPP metro investments are designed to be designed-build-operate-transfer-and thus make PPP / BOT possible / attractive. 
9- Renting of tunnels and stations for fiber-optic lines can increase the revenue of the rail system.

10- If PPP / BOT is not feasible in subway projects, PPP / BOT should be surveyed in projects with low investment cost, such as low-altitude, light subway, cable car, funicular, street tram.

Planning, financing, construction, operation, real estate appraisal, expropriation of rail system lines together with our above evaluations; in order to be managed more effectively from a single rule, the Rails Systems should be managed by an independent organization structure under the Metropolitan Municipality. Thus, it may be possible to provide more flexible and effective financing with the legal remedies.

\section{VI.CONCLUSION}

Strategies for Value Capture, the applicability of the method in Turkey are summarized in the following table.

Table 9. Value Capture Strategies for Applicability Turkey

\begin{tabular}{|c|c|c|}
\hline $\begin{array}{l}\text { Value Cap- } \\
\text { ture Strategies } \\
\text { (VCS) }\end{array}$ & Definition of Method & $\begin{array}{l}\text { Applicability } \\
\text { of Method. }\end{array}$ \\
\hline $\begin{array}{l}\text { Split-rate } \\
\text { property tax, }\end{array}$ & $\begin{array}{l}\text { Real estate value tax includes both } \\
\text { land tax and all taxes applied to the } \\
\text { annexes such as the building on the } \\
\text { land. }\end{array}$ & $\begin{array}{l}\text { Applicability } \\
\text { requires legal } \\
\text { regulation. }\end{array}$ \\
\hline $\begin{array}{l}\text { Tax Increment } \\
\text { Financing }\end{array}$ & $\begin{array}{l}\text { Basically, this method predicts the } \\
\text { allocation of the shares for the led } \\
\text { systems from the tax collected from } \\
\text { the place where the value increase } \\
\text { in the transfer of the resulting value } \\
\text { increases to the public is realized. }\end{array}$ & $\begin{array}{l}\text { Applicability } \\
\text { requires legal } \\
\text { regulation. }\end{array}$ \\
\hline $\begin{array}{l}\text { Special } \\
\text { assesment } \\
\text { district }\end{array}$ & $\begin{array}{l}\text { The end result of investing in hono- } \\
\text { rable system is the price paid by the } \\
\text { owners of the growing real estate. }\end{array}$ & $\begin{array}{l}\text { Applicability } \\
\text { requires legal } \\
\text { regulation. }\end{array}$ \\
\hline $\begin{array}{l}\text { Joint Develop- } \\
\text { ment }\end{array}$ & $\begin{array}{l}\text { Real estate development is a } \\
\text { multi-faceted business area and it } \\
\text { involves various actions regarding } \\
\text { building construction, marketing } \\
\text { operation and management without } \\
\text { developing land. }\end{array}$ & $\begin{array}{l}\text { Applicable. } \\
\text { Legal basis: } \\
\text { Metropolitan } \\
\text { Municipality } \\
\text { Law No. } 5216 \\
\text { Municipality } \\
\text { Law No. } 5393\end{array}$ \\
\hline Air Rights & $\begin{array}{l}\text { The concept of the right of air } \\
\text { expresses the means by which } \\
\text { central or local governments } \\
\text { allocate land for their transportation } \\
\text { investments by providing income by } \\
\text { opening these land to various uses } \\
\text { in order to meet some or all of the } \\
\text { transportation investment costs. }\end{array}$ & $\begin{array}{l}\text { Applicable. } \\
\text { Legal basis: } \\
\text { Metropolitan } \\
\text { Municipality } \\
\text { Law No. } 5216\end{array}$ \\
\hline
\end{tabular}

In determining the Financing of a Rail System project and the Value Increasing Strategy, it is necessary to follow various steps. Firstly, priority projects should be determined in accordance with the strategic transportation plan. A comprehensive feasibility study should be carried out for the selected projects. It should be decided which of the financing models is more appropriate for the projects whose feasibility is completed. There is no single financing model that can be applied to all different projects. A financing model suitable for the nature of the project (cost, life, income, risks) should be selected. More than one value capture strategy can be used in a project.

Under the proposed financing model principles, different and flexible financing models can be produced for any project considered. It is not possible to define a single standard financing model and apply it to all different quality projects (such as motorways and high-speed train projects).

The current legislation of Turkey, allows the implementation of only BOT and BO financing models. Therefore, the current trends seen all over the world shows that it is necessary to establish new laws and the Regulations allowing the PPP model for Turkey.

Value-added strategies for Istanbul were handled with public administrations, construction contractors and real estate appraisers. It has been proposed in this study that the selection of appropriate public-private cooperation models and which alternative financing methods can be used. Future research should explore how much of the investment cost can be met in a few years by using value capture strategies on a tracked system grid.

\section{REFERENCES}

[1] Yescombe, E.R., Principles of Project Finance, 2002.

[2] Dr.Azadeh Kopp-Moini, XS-Axis Consulting GmbH, Unpublished Presentation, Railway PPPs "Trends, PPP Relavant Issues", Hamburg, Germany,2013. http://www.unece. org/fileadmin/DAM/ceci/documents/2014/PPP_Materclass/ Day3_Azadeh_Kopp_Railway_PPP.pdf

[3] Julien Dehornoy, PPPs in the rail sector - A review of 27 projects, SNCF French National Railways, April 2012. https:// mpra.ub.uni-muenchen.de/38415/1/MPRA_paper_38415. pdf

[4] Istanbul Metropolitan Municipality 2016 Year Investment and Service Program, 2016,

[5] Lari, Adil and Levinson, David and Zhao, Zhirong and Iacono, Value Capture of Transportation Finance, Tecnical Research Report, Minneapolis,2009.

[6] Ismail Eraslan et al., Istanbul Property Value Map Study, IMM, Istanbul, 2017. 
[7] Z Zhao, Levinson D., Introduction to The Special Issue on Value Capture for Transportation Finance, The Journal Transport of Land Use, University of Minnesote,2012.

[8] Suzuki, H. J Murakami, Y. Hong, and B. Tamayose, Finacing Transist-Oriented Development with Land Values: Adapting Land Value in Developing Countries, Washington D.C., Urban Development Series, World Bank Group, 2015.

[9] R. W. Saaty, The Analytıc Hierarchy Process-What It is And How It is Used, Math Modeling, 1987.
[10] Finnerty, J.D. Project Financing: Asset-Based Financial Engineering. John D. Wiley \& Sons, 1996.

[11] Khan, MFK and Parra R.J. Financing Large Project Using Project Finance Techniques and Practices, 2003.

[12] Istanbul Metropolitan Municipality, Transportation Master Plan, Alternative Financing Swot Analysis, 2002, Istanbul, Turkey.

[13] Istanbul Electricity, Tramway and Tunnel General Management, Public Transport, Tunnel, Istanbul, 2018. http://www. iett.istanbul/en/main/pages/tunnel/154 